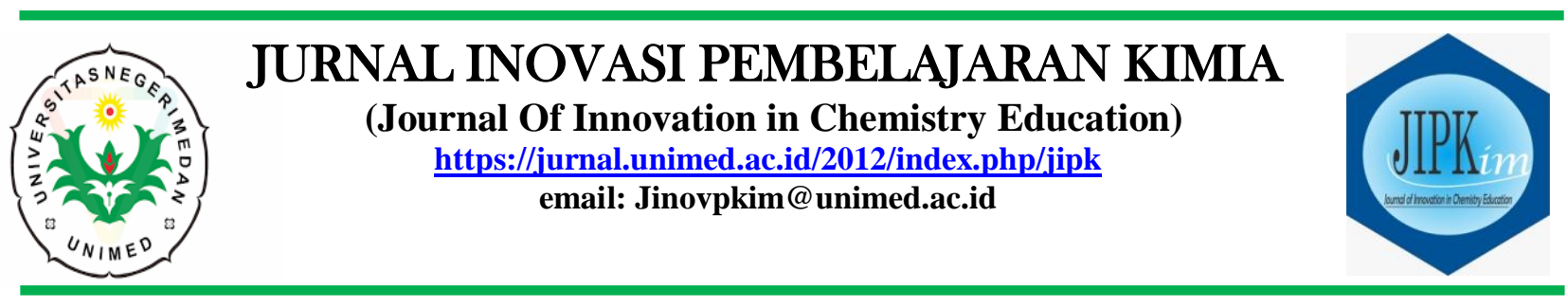

$\begin{array}{ll}\text { Masuk } & : \text { 23 September } 2021 \\ \text { Revisi } & : \text { 8 Oktober } 2021 \\ \text { Diterima } & : \text { 22 Oktober } 2021 \\ \text { Diterbitkan } & : \text { 30 Oktober } 2021 \\ \text { Halaman } & : \text { 136 }-147\end{array}$

\title{
Pengembangan Handout Titrasi Asam-Basa Berbasis Android Terintegrasi Model Discovery Learning dan Soal-soal HOTS
}

\author{
Catur Kurniawan ${ }^{1 *}$, Iis Siti Jahro ${ }^{1}$ \\ ${ }^{1}$ Program Studi Pendidikan Kimia, Universitas Negeri Medan, Medan \\ *Alamat Korespondensi: caturkurniawan1503@gmail.com
}

\begin{abstract}
This research aims to determine: (1) Analysis results regarding to the advantages and disadvantages of acid-base titration handout in internet, (2) Feasibility level of the Acid-Base Titration Handout Based on Android Integrated Discovery Learning Model and HOTS Problems which has been developed, (3) Students' and teachers' response to the Acid-Base Titration Handout Based on Android Integrated Discovery Learning Model and HOTS Problems which has been developed. The type of research is $(R \& D)$ by implementing 4-D development model by Thiagarajan. The stages are define, design, develop, and disseminate. The Acid-Base Titration Handout Based on Android Integrated Discovery Learning Model and HOTS Problems which has been developed was validated by 5 experts and obtained score $94.72 ; 96.14 ; 99.10 ; 95.00$ and $98.11 \%$ respectively which is categorized as very feasible. Students's and teachers's responses toward Acid-Base Titration Handout Based on Android Integrated Discovery Learning Model and HOTS Problems are categorized as very good by percentage 91.27 and 100\%. It shows that The Acid-Base Titration Handout Based on Android Integrated Discovery Learning Model and HOTS Problems is appropriate to implement for teaching and learning process
\end{abstract}

Keywords: R\&D, Acid-base titration, Handout, Discovery Learning, HOTS problems

\section{PENDAHULUAN}

Perkembangan erat kaitannya dengan revolusi Industri 4.0 ditandai dengan meluasnya penggunaan teknologi di segala aspek kehidupan, tak terkecuali di bidang pendidikan. Media pembelajaran merupakan kontribusi teknologi dalam dunia pendidikan. Menurut (Tafonao, 2018), media pembelajaran adalah segala sesuatu yang dapat digunakan untuk menyampaikan pesan guru kepada siswa sehingga dapat merangsang pikiran, perasaan, perhatian, minat, dan motivasi siswa. Media pembelajaran berbasis android merupakan wujud dari teknologi dalam pendidikan. Hal ini didukung dengan banyaknya siswa khususnya siswa tingkat SMA yang menjadikan android sebagai kebutuhan primer (Lubis \& Ikhsan, 2015).

Penelitian tentang pengembangan media pembelajaran berbasis android telah banyak dilakukan dan sebagian besar memberikan dampak positif bagi siswa Prasetyo et al. (2014), menyatakan bahwa penerapan media pembelajaran kimia berbasis Android secara signifikan dapat meningkatkan motivasi belajar siswa pada materi koloid, Harianto et al. (2017) 
menyatakan bahwa media pembelajaran Android efektif dapat menumbuhkan literasi sains siswa pada materi reaksi redoks dan elektrokimia. Ulfa et al. (2017), menyatakan bahwa penerapan media pembelajaran berbasis android dapat meningkatkan kreativitas dan prestasi kognitif siswa pada materi stoikiometri, dan Ramadhani et al. (2016), menyatakan bahwa penerapan media pembelajaran berbasis android mampu meningkatkan hasil belajar siswa pada materi koloid.

Kimia adalah cabang ilmu yang mempelajari sifat-sifat materi, struktur materi, perubahan materi, dan energi yang terlibat dalam reaks. Penguasaan konsep yang kuat sangat penting dalam mempelajari kimia. Konsep-konsep tersebut saling berkaitan satu sama lain sehingga seringkali menyulitkan siswa.

Kesulitan siswa dalam mempelajari kimia akan terus berlanjut jika tidak segera diatasi. Salah satu bahan kimia yang dianggap sulit adalah titrasi asam basa. Menurut Marzuki \& Astuti (2017), siswa menggambarkan proses netralisasi sebagai pencampuran asam-basa fisik yang tidak menghasilkan produk dan tidak memiliki persamaan reaksi.

Handout merupakan bahan ajar yang berisi sekumpulan materi, baik yang baru maupun yang mendalam, yang penting bagi siswa. Handout dapat digunakan sebagai bahan ajar yang praktis dan ekonomis. Selain itu handout juga dapat dijadikan sebagai bahan referensi dan pengingat bagi siswa saat belajar online karena mengandung materi yang sistematis. Menurut Ulya et al. (2015), handout memiliki beberapa keunggulan, yaitu (1) sebagai pendamping penjelasan guru, (2) sebagai catatan siswa, (3) sebagai bahan referensi bagi siswa, (4) sebagai pengingat materi pelajaran, (5) memotivasi siswa untuk mencari tahu lebih dalam, (6) memberikan umpan balik anggota, dan (7) menilai hasil belajar. Menurut Fatikhakh et al. (2018) dan berdasarkan pengalaman peneliti selama magang 1, 2 dan 3, bahan ajar berupa handout terutama yang terintegrasi dengan soal HOTS sangat jarang ditemukan, padahal kemampuan HOTS sangat menentukan tingkat mutu pendidikan menurut ke PISA (Programmed International Science Assessment) dan TIMSS (Trends International Mathematics and Science Study).

\section{KAJIAN LITERATUR}

\section{Penelitian dan Pengembangan $(R \& D)$}

Menurut Gay et al. (2012), penelitian dan pengembangan (R\&D) adalah proses pemberitahuan kebutuhan konsumen yang bertujuan untuk menghasilkan produk untuk memenuhi kebutuhan konsumen. Penelitian dan Pengembangan (R\&D) yang dilakukan di bidang pendidikan atau sekolah bertujuan untuk mengetahui kebutuhan mata pelajaran pendidikan, baik guru maupun siswa, terutama dalam hal media pembelajaran, bahan ajar, kurikulum, atau sistem manajemen. Penelitian dan pengembangan (R\&D) umumnya tidak bergantung pada tujuan, personel, atau waktu penyelesaian. Dalam penelitian dan pengembangan (R\&D), produk yang dikembangkan harus sesuai dengan standar yang berlaku. Setelah selesai, produk yang dikembangkan akan diuji di lapangan dan direvisi hingga tercapai kualitas. Siklus penelitian sangat panjang dan tidak mudah, tetapi sangat penting untuk menghasilkan produk yang benar-benar sesuai dengan standar.

\section{Handout}

Handout adalah buku pegangan siswa yang berisi materi pelajaran secara lengkap. Handout menyediakan semua materi yang harus dipelajari. Handout berbeda dari modul yang isinya disajikan per unit materi terkecil. Namun handout dan modul masih memiliki kesamaan yaitu memuat komponenkomponen yang dibutuhkan dalam pembelajaran seperti tujuan/kompetensi pembelajaran, prosedur pembelajaran, materi pembelajaran, latihan, tugas, dan soal evaluasi (Munawaroh, 2014).

\section{Android}

Android adalah sistem operasi yang dibangun oleh Google. Sistem operasi 
android berbasis kernel Linux. Saat ini, Android merupakan jenis smartphone yang paling banyak digunakan (Chinetha et al., 2015). Menurut Haris et al. (2017), Permintaan smartphone Android terus meningkat setiap hari bahkan menguasai pangsa pasar dunia sebesar $86,8 \%$. Android telah banyak digunakan dalam proses leaning. Menurut Prasetyo et al. (2014), penerapan media pembelajaran kimia berbasis Android secara signifikan dapat meningkatkan motivasi belajar siswa pada materi koloid, Harianto et al. (2017), menyatakan bahwa media pembelajaran Android efektif dapat menumbuhkan literasi sains siswa pada materi reaksi redoks dan elektrokimia, Ulfa et al. (2017), menyatakan bahwa penerapan media pembelajaran berbasis android dapat meningkatkan kreativitas dan prestasi kognitif siswa pada materi stoikiometri, dan Ramadhani et al. (2016), menyatakan bahwa penerapan media pembelajaran berbasis android mampu meningkatkan hasil belajar siswa pada materi koloid.

\section{Discovery Learning}

Menurut (Sumantri, 2015), model pembelajaran discovery learning adalah suatu cara penyajian materi dimana siswa dikondisikan untuk menemukan sendiri konsep, prinsip, dan pemecahan masalah yang harus dikuasai untuk mencapai tujuan pembelajaran. Penerapan model discovery learning memungkinkan siswa untuk menemukan informasi dan materi yang dibutuhkan sebelum ada penjelasan atau penguatan yang diberikan oleh pendidik.

Penerapan model discovery learning dinilai sesuai dengan kurikulum 2013 yang sangat berpusat pada siswa dan menerapkan pendekatan saintifik (Feriyanti, 2014). Kesesuaian penerapan model discovery learning juga didukung oleh beberapa penelitian lain oleh Ramadhani et al. (2016), Ellizar et al. (2019), dan (Khabibah et al., 2017) yang masing-masing menyimpulkan bahwa penerapan model discovery learning baik dalam pengajaran maupun pengembangan bahan ajar dapat meningkatkan prestasi belajar, hasil belajar, keterampilan berpikir kritis, dan keterampilan sains siswa.

Model pembelajaran discovery memiliki 6 sintaks atau tahapan pembelajaran, yaitu: (1) Stimulasi, (2) Pernyataan masalah, (3) Pengumpulan data, (4) Pengolahan data, (5) Verifikasi, dan (6) Generalisasi (Sinambela, 2013)

\section{Higher Order Thinking Skills (HOTS)}

Kurikulum 2013 sendiri menuntut siswa untuk memiliki Higher Order Thinking Skills (HOTS) atau kemampuan berpikir tingkat tinggi. Menurut Anggraini (2018), Higher Order Thinking Skills adalah kemampuan untuk menghubungkan, memanipulasi, dan menggunakan pengetahuan dan pengalaman yang dimiliki siswa untuk berpikir kritis dan kreatif dalam memecahkan suatu masalah. Pendapat lain tentang HOTS dikemukakan oleh Bloom dalam Djami \& Kuswandono (2020), yang mendefinisikan HOTS sebagai kemampuan di atas pengetahuan (C1), pemahaman $(\mathrm{C} 2)$, dan penerapan $(\mathrm{C} 3)$, tetapi sudah masuk ke ranah analisis (C4). sintesis (C5), dan evaluasi (C6). Berdasarkan uraian di atas, dapat disimpulkan bahwa soal HOTS merupakan soal yang dijiwai oleh indikator C4, C5, dan C6 dari taksonomi Bloom.

$$
\text { Berdasarkan hasil penelitian }
$$
sebelumnya, kemampuan HOTS siswa di Indonesia terhadap kimia masih rendah. Hal ini berdasarkan kesimpulan penelitian Habiddin \& Page (2019) yang menyatakan bahwa jumlah siswa yang mampu menjawab soal HOTS kimia kinetik dengan benar masih sedikit. Hasil serupa juga disimpulkan dalam penelitian yang dilakukan oleh Harta et al. (2020) bahwa kemampuan siswa SMP di Yogyakarta dalam menjawab soal HOTS masih tergolong lemah, bahkan menurut penelitian Abdullah et al. (2018), kemampuan HOTS calon guru di Indonesia masih tergolong sedang. Oleh karena itu, sangat penting untuk mengembangkan media terintegrasi HOTS. 


\section{METODE}

Jenis penelitian ini adalah Penelitian dan Pengembangan (R\&D). Produk yang dikembangkan adalah Handout Titrasi AsamBasa Berbasis Android Terintegrasi Model Discovery Learning dan Soal-soal HOTS. Model pengembangan yang diterapkan adalah 4-D oleh Thiagarajan. Tahapan model pengembangan 4D meliputi: 1) Define; 2) Desain; 3) Mengembangkan; dan 4) Menyebarkan.

\section{Pengembangan}

Prosedur pengembangan 4D (Define, Design, Develop, dan Disseminate) adalah sebagai berikut:

1. Define

Define adalah tahapan untuk menentukan dan mendefinisikan kebutuhan pembelajaran. Tahapan ini meliputi 5 poin utama, yaitu:

1) Analisis ujung depan, bertujuan untuk menemukan dan menentukan masalah dasar siswa pada mata pelajaran kimia pada materi titrasi asam basa. Tahapan ini dilakukan peneliti melalui observasi dengan mewawancarai 2 orang guru kimia di SMA Negeri 10 Medan. Pada tahap ini peneliti juga menentukan analisis kelemahan dan kelebihan (berdasarkan BSNP) terhadap handout titrasi asam basa di internet.

2) Analisis siswa, bertujuan untuk mengetahui karakteristik siswa termasuk kebutuhan siswa dan juga karakteristik belajar siswa sehingga peneliti dapat menentukan jenis pengembangan yang sesuai terhadap siswa.

3) Analisis konsep bertujuan untuk mengidentifikasi konsep atau materi utama yang harus diajarkan berdasarkan silabus untuk menyusun materi titrasi asam basa secara sistematis.

4) Analisis tugas, bertujuan untuk mengetahui tugas pokok yang harus dikuasai siswa untuk mencapai kompetensi minimal.

5) Perumusan tujuan pembelajaran bertujuan untuk menghasilkan tujuan pembelajaran berdasarkan analisis tugas dan analisis konsep yang telah dilakukan.

\section{Design}

Tahap design dilakukan untuk merancang Handout Titrasi Asam-Basa Berbasis Android Terintegrasi Model Discovery Learning dan Soal-soal HOTS yang sesuai dengan kebutuhan siswa berdasarkan tahap definisi. Hal-hal yang dilakukan pada tahap ini adalah:

a. Pemilihan media, media yang dipilih dalam penelitian pengembangan ini berupa handout berbasis android.

b. Pemilihan format, format yang dipilih harus sesuai dengan media yang akan dikembangkan yaitu handout berbasis android berdasarkan standar BSNP.

c. Perancangan awal, perancangan awal adalah rancangan materi titrasi asam basa yang dibuat dengan menggunakan referensi dari beberapa buku kimia kelas XI pada kurikulum 2013, sumber internet, dan juga menentukan aplikasi yang akan digunakan untuk membuat produk handout berbasis android.

\section{Develop}

Tahap develop meliputi berikut ini:

a. Pembuatan handout berbasis produk android, pada tahap ini peneliti membuat produk menggunakan aplikasi sketchware.

b. Validasi bahan ajar oleh validator ahli, pada tahap ini peneliti meminta bantuan 3 orang dosen kimia Universitas Negeri Medan dan 2 orang guru kimia SMA Negeri 10 Medan untuk memvalidasi handout berbasis android.

c. Uji coba lapangan, peneliti mengumpulkan data kualitatif berupa respon siswa dan guru untuk mengetahui kualitas produk yang telah dikembangkan.

\section{Disseminate}

Dalam penelitian ini, disseminate dilakukan dengan mengunggah produk ke playstore agar dapat diakses oleh siswa atau guru kimia.

\section{Pelaksanaan}

Waktu dan Lokasi Penelitian

Penelitian ini dilakukan kurang lebih selama 4 bulan mulai dari 25 Februari 
2021 sampai 8 Juni 2021. Tahap penelitian meliputi pengembangan produk dan implementasi dalam rangka untuk mendapatkan respon siswa. Pengembangan produk dilakukan di kost peneliti di Jalan Bilal Ujung Nomor 288B Pulo Brayan Darat, Medan. Sedangkan pelaksanaannya dilakukan di SMA Negeri 10 Medan.

Populasi dan Sampel

Populasi adalah siswa kelas XI MIA

1 SMA Negeri 10 Medan Tahun Pelajaran 2020/2021. Untuk memperoleh respon siswa secara besar-besaran terhadap siswa satu kelas, maka sampel dalam penelitian ini adalah seluruh siswa kelas XI MIA 1 SMA Negeri 10 Medan.

\section{Instrumen Validasi Handout Berbasis Android}

Instrumen validasi yang digunakan dalam penelitian ini diambil dari Badan Standar Nasional Pendidikan (BSNP). Dalam penelitian ini skala yang digunakan adalah Likert dengan 4 alternatif jawaban yang dibuat dalam bentuk checklist. Skala Likert terdiri dari sejumlah pernyataan mengenai penilaian suatu media. Untuk memperoleh data kuantitatif, setiap alternatif jawaban diberi skor, yaitu: 1 = Sangat tidak layak; $2=$ Tidak Layak; 3 = Layak; 4 = Sangat Layak. Berikut kisi-kisi instrumen validasi handout berbasis android menurut BSNP 2014.

Skala penilaian yang digunakan adalah 1 sampai 4 yaitu skor 1 adalah skor terendah dan skor 4 adalah skor tertinggi. Tingkat kelayakan (P) dihitung dengan persamaan berikut:

$$
\mathrm{P}=\frac{\text { skor yang diperoleh }}{\text { skor maksimum }} \times 100 \%
$$

kemudian dikategorisasikan berdasarkan tabel berikut:
Tabel 1. Kategori Kelayakan Handout Berbasis Android

\begin{tabular}{ccc}
\hline No. & Skor $(\%)$ & Kategori Kelayakan \\
\hline 1 & $<21 \%$ & Sangat tidak layak \\
2 & $21-40 \%$ & Tidak layak \\
3 & $41-60 \%$ & Cukup \\
4 & $61-80 \%$ & Layak \\
5 & $81-100 \%$ & Sangat layak \\
\hline
\end{tabular}

\section{Angket Respon Siswa dan Guru}

Kuesioner yang digunakan untuk memperoleh respon siswa dan guru mengadopsi skala Guttman dengan 2 alternatif pilihan. Semua item dihitung dengan skor total, kemudian dianalisis menggunakan rumus:

$$
\text { Skor }=\frac{\text { skor total semuasiswa }}{\text { skormaksimal }} \times 100 \%
$$

dan dikategorikan berdasarkan tabel berikut:

Tabel 2. Kategori Respon

\begin{tabular}{ccc}
\hline No. & Skor $(\%)$ & Kategori \\
\hline 1. & $86-100$ & Sangat baik \\
2. & $76-86$ & Baik \\
3. & $56-75$ & Cukup \\
4. & $55-59$ & Kurang \\
5. & $0-54$ & Sangat kurang \\
\hline
\end{tabular}

\section{HASIL DAN PEMBAHASAN \\ Tahap Define}

1. Analisis Ujung Depan

Berdasarkan analisis dari hasil wawancara ditemukan bahwa:

1. Sumber belajar kimia yang digunakan masih kurang, terutama pada masa pandemi Covid-19. Sumber belajar siswa hanya dari buku pegangan yang sulit dipahami dan tidak dapat mengarahkan siswa untuk belajar mandiri dan menggali ilmu

2. Guru belum pernah membuat bahan ajar berupa handout berbasis android sehingga pemanfaatan android dikalangan siswa belum optimal untuk proses pembelajaran

3. Pencapaian tujuan pembelajaran masih belum maksimal

4. Guru dalam mengajar masih sering menggunakan metode teacher-centered 
belum banyak pendekatan saintifik sesuai Kurikulum 2013

5. Sumber belajar masih belum mengimplementasikan soal HOTS.

Pada tahap define peneliti juga menentukan analisis terkait kelebihan dan kekurangan (berbasis BSNP) 3 materi titrasi asam basa diperoleh dari internet. Hasil analisis kelemahan dan kelebihan handout titrasi asam basa di internet adalah sebagai berikut:

Kelemahan :

$\checkmark$ Tidak dilengkapi KI, KD, Indikator, dan Tujuan Pembelajaran sehingga penyajian materi kurang sistematis

$\checkmark$ Ruang lingkup materi dan penjelasan kurang luas dan kurang mendalam

$\checkmark$ Mereka tidak mengintegrasikan pendekatan saintifik sehingga kurang merangsang rasa ingin tahu siswa

$\checkmark$ Mereka tidak dilengkapi dengan gambar, ilustrasi, dan fakta atau aplikasi dalam kehidupan sehari-hari

$\checkmark$ Mereka tidak dilengkapi dengan banyak soal khususnya HOTS.

Kelebihan :

$\checkmark$ Penyajian rumus yang lengkap dan mudah diingat

$\checkmark$ Penyajian contoh soal dan pembahasan

$\checkmark$ Dilengkapi dengan kurva titrasi asam basa

\section{Analisis Siswa}

Gambar 1. menunjukkan minat siswa terhadap pelajaran kimia masih kurang, hal ini dibuktikan dengan persentase siswa yang menyukai pelajaran kimia sebanyak $14,8 \%$ sedangkan persentase siswa yang tertarik pada mata pelajaran biologi lebih tinggi yaitu sebanyak $25,9 \%$. Selain itu, sebanyak $70,4 \%$ siswa menyatakan bahwa mata pelajaran kimia kurang menyenangkan karena berkaitan dengan konsep, teori, perhitungan, dan persamaan reaksi, bahkan sebanyak $77,8 \%$ siswa terkadang masih mengalam kesulitan yaitu pada titrasi asam basa. materi sebanyak 51,9\% siswa menyatakan hal yang sama.

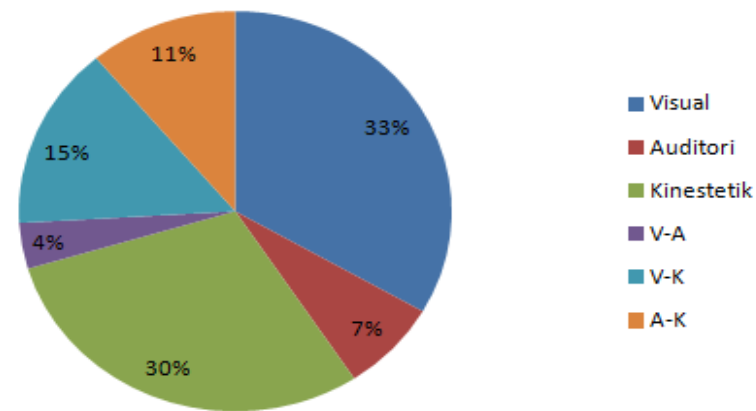

Gambar 1. Diagram Gaya Belajar Siswa Hasil analisis gaya belajar siswa menunjukkan bahwa $33 \%$ siswa memiliki gaya belajar visual, $30 \%$ kinestetik, $15 \%$ visual kinestetik, $11 \%$ auditory kinestetik, $7 \%$ auditory, dan $4 \%$ visual auditory.

\section{Analisis Tugas}

Tahap analisis tugas dilakukan dengan menganalisis keseluruhan kompetensi yang dibutuhkan pada mata pelajaran yang disesuaikan dengan kompetensi dasar pada materi titrasi asam basa, yaitu: Menentukan konsentrasi larutan asam atau basa dan menentukan $\mathrm{pH}$ campuran berdasarkan data hasil titrasi asam basa. Berdasarkan kompetensi dasar tersebut, mahasiswa diharapkan:

1. Mampu memahami pengertian titrasi asam basa

2. Mampu memahami prinsip-prinsip titrasi asam basa

3. Mampu menentukan indikator yang tepat dalam titrasi asam basa asam basa

4. Mampu menentukan konsentrasi asam atau basa dengan titrasi

5. Mampu menghitung $\mathrm{pH}$ titrasi asam basa

6. Mampu menentukan kurva titrasi asam basa

\section{Analisis Konsep}

Pada tahap ini konsep materi pembelajaran disusun untuk memudahkan siswa dalam memahami titrasi asam basa materi dan mencapai kompetensi yang diharapkan. Konsep materi yang harus diajarkan dalam materi titrasi asam basa antara lain :

1. Menentukan konsentrasi titrasi-asam basa 
2. Menentukan indikator titrasi asam-basa

3. Menentukan kurva titrasi asam basa

4. Menentukan $\mathrm{pH}$ titrasi asam basa

5. Menentukan Tujuan Pembelajaran

Tahap ini bertujuan untuk membuat landasan dasar dalam mempersiapkan tes dan merancang bahan ajar yang akan digunakan. Tujuan pembelajaran materi titrasi asam-basa adalah :

1. Siswa mampu memahami pengertian titrasi asam-basa

2. Siswa mampu memahami prinsipprinsip titrasi asam-basa

3. Siswa mampu mengetahui jenis-jenis indikator titrasi asam-basa

4. Siswa mampu mampu menentukan indikator yang tepat digunakan untuk titrasi asam-basa

5. Siswa mampu menentukan titik ekivalen dan titik akhir titrasi asam basa

6. Siswa mampu menentukan konsentrasi asam atau basa dengan titrasi asam-basa

7. Siswa mampu menentukan $\mathrm{pH}$ campuran pada berbagai jenis titrasi asam-basa

8. Siswa mampu membuat kurva titrasi asam-basa

\section{Tahap Design}

a. Pemilihan Media

Media yang dipilih adalah android, hal ini disesuaikan dengan hasil analisis front and end yang dilakukan peneliti dengan mewawancarai 2 orang kimia guru di SMA Negeri 10 Medan yang menyatakan bahwa sebagian besar siswa memiliki android namun belum memanfaatkannya secara optimal untuk menunjang proses pembelajaran di kelas.

b. Pemilihan Format

Format yang dipilih dalam pengembangan ini berupa handout titrasi asam basa yang diintegrasikan dengan model pembelajaran discovery learning dan dilengkapi dengan soal-soal HOTS.

c. Desain awal

Desain awal dalam pengembangan ini berupa draft handout titrasi asam basa yang terintegrasi dengan model discovery learning dan dilengkapi dengan soal-soal HOTS yang disusun menggunakan Microsoft word 2007. Bagian-bagian dari handout draft ini meliputi profil penyusun, kompetensi, materi , link video titrasi asam basa dari youtube, LKPD berupa praktikum, dan soal HOTS.

\section{Tahap Develope}

a. Pembuatan Handout Berbasis Android

Handout Titrasi Asam-Basa bebasis

Android Terintegrasi Model Discovery Learning dan Soal-soal HOTS dibuat dengan menggunakan aplikasi "sketchware". Produk tersebut diberi nama Handout Titrasi AsamBasa dengan ukuran file 7,7 MB.

Berikut ini adalah bagian-bagian dari aplikasi pembelajaran berbasis

Tabel 3. Komponen Aplikasi Pembelajaran yang Dikembangkan

\begin{tabular}{|c|c|c|}
\hline No & Komponen & Deskripsi \\
\hline 1. & Ikon Aplikasi & $\begin{array}{l}\text { Berbentuk gambar atom } \\
\text { yang menampilkan bahan } \\
\text { ajar kimia }\end{array}$ \\
\hline 2. & Splash Screen & $\begin{array}{l}\text { Tampilan animasi berupa } \\
\text { larutan dan dilengkapi } \\
\text { dengan nama produk }\end{array}$ \\
\hline 3. & Homepage & $\begin{array}{l}\text { Berisi beberapa menu yaitu } \\
\text { profil, kompetensi, materi, } \\
\text { video, praktikum, serta soal } \\
\text { HOTS }\end{array}$ \\
\hline 4. & Menu Profil & $\begin{array}{l}\text { Berisi informasi penyusun } \\
\text { aplikasi pembelajaran }\end{array}$ \\
\hline 5. & $\begin{array}{l}\text { Menu } \\
\text { Kompetensi }\end{array}$ & $\begin{array}{l}\text { Berisi beberapa kompetensi } \\
\text { seperti kompetensi inti, } \\
\text { kompetensi dasar, indikator, } \\
\text { dan tujuan }\end{array}$ \\
\hline 6 & Menu Materi & $\begin{array}{lr}\text { Berisi materi titrasi } & \text { asam- } \\
\text { basa yan disusun } \\
\text { berdasarkan } \\
\text { discovery learning }\end{array}$ \\
\hline 7. & Menu Video & $\begin{array}{l}\text { Berisi beberapa video titrasi } \\
\text { asam-basa diambil dari } \\
\text { youtube }\end{array}$ \\
\hline 8. & $\begin{array}{l}\text { Menu } \\
\text { Praktikum }\end{array}$ & $\begin{array}{l}\text { Berisi lembar praktikum } \\
\text { titrasi asam-basa }\end{array}$ \\
\hline 9. & $\begin{array}{l}\text { Menu Soal- } \\
\text { soal HOTS }\end{array}$ & $\begin{array}{l}\text { Berisi } 30 \text { Soal HOTS titrasi } \\
\text { asam basa dalam bentuk } \\
\text { kuis dan pengguna dapat } \\
\text { mengetahui jawabannya } \\
\text { secara langsung. }\end{array}$ \\
\hline
\end{tabular}


b. Validasi

Validasi dilakukan terhadap 5 validator yang terdiri dari 3 orang dosen dan 2 orang guru. Hasil dari tahapan ini adalah sebagai berikut:

Tabel 4. Hasil Validasi Kelayakan oleh

Dosen 1

\begin{tabular}{ccc}
\hline $\begin{array}{c}\text { Aspek yang } \\
\text { Dinilai }\end{array}$ & $\begin{array}{c}\text { Persentase } \\
\text { Kelayakan }\end{array}$ & Kategori \\
\hline $\begin{array}{c}\text { Kelayakan Isi } \\
\text { Kelayakan } \\
\text { Bahasa }\end{array}$ & 90.38 & Sangat Layak \\
$\begin{array}{c}\text { Kelayakan } \\
\text { Penyajian }\end{array}$ & 96.43 & Sangat Layak \\
$\begin{array}{c}\text { Kelayakan } \\
\text { Kegrafikan }\end{array}$ & 93.75 & Sangat Layak \\
\hline
\end{tabular}

Tabel 5. Hasil Validasi Kelayakan oleh Dosen 2

\begin{tabular}{ccc}
\hline $\begin{array}{c}\text { Aspek yang } \\
\text { Dinilai }\end{array}$ & $\begin{array}{c}\text { Persentase } \\
\text { Kelayakan }\end{array}$ & Kategori \\
\hline $\begin{array}{c}\text { Kelayakan Isi } \\
\text { Kelayakan } \\
\text { Bahasa }\end{array}$ & 96.15 & Sangat Layak \\
$\begin{array}{c}\text { Kelayakan } \\
\text { Penyajian }\end{array}$ & 96.43 & Sangat Layak \\
$\begin{array}{c}\text { Kelayakan } \\
\text { Kegrafikan }\end{array}$ & 95.31 & Sangat Layak \\
\hline
\end{tabular}

Table 6. Hasil Validasi Kelayakan oleh Dosen 3

\begin{tabular}{ccc}
\hline $\begin{array}{c}\text { Aspek yang } \\
\text { Dinilai }\end{array}$ & $\begin{array}{c}\text { Persentase } \\
\text { Kelayakan }\end{array}$ & Kategori \\
\hline $\begin{array}{c}\text { Kelayakan Isi } \\
\text { Kelayakan } \\
\text { Bahasa }\end{array}$ & 100 & Sangat Layak \\
$\begin{array}{c}\text { Kelayakan } \\
\text { Penyajian }\end{array}$ & 96.43 & Sangat Layak \\
$\begin{array}{c}\text { Kelayakan } \\
\text { Kegrafikan }\end{array}$ & 100 & Sangat Layak \\
\hline
\end{tabular}

Tabel 7. Hasil Validasi Kelayakan oleh Guru 1

\begin{tabular}{ccc}
\hline $\begin{array}{c}\text { Aspek yang } \\
\text { Dinilai }\end{array}$ & $\begin{array}{c}\text { Persentase } \\
\text { Kelayakan }\end{array}$ & Category \\
\hline $\begin{array}{c}\text { Kelayakan Isi } \\
\text { Kelayakan } \\
\text { Bahasa }\end{array}$ & 95.19 & Sangat Layak \\
$\begin{array}{c}\text { Kelayakan } \\
\text { Penyajian }\end{array}$ & 94.64 & Sangat Layak \\
$\begin{array}{c}\text { Kelayakan } \\
\text { Kegrafikan }\end{array}$ & 96.87 & Sangat Layak \\
\hline
\end{tabular}

Tabel 8. Hasil Validasi Kelayakan oleh Guru 2

\begin{tabular}{lcc}
\hline \multicolumn{1}{c}{$\begin{array}{c}\text { Aspek yang } \\
\text { Dinilai }\end{array}$} & $\begin{array}{c}\text { Persentase } \\
\text { Kelayakan }\end{array}$ & Kategori \\
\hline Kelayakan Isi & 99.04 & Sangat Layak \\
$\begin{array}{l}\text { Kelayakan } \\
\text { Bahasa }\end{array}$ & 98.21 & Sangat Layak \\
$\begin{array}{l}\text { Kelayakan } \\
\begin{array}{l}\text { Penyajian } \\
\text { Kelayakan } \\
\text { Kegrafikan }\end{array}\end{array}$ & 96.87 & Sangat Layak \\
\hline
\end{tabular}

Kegrafikan

Penilaian Handout Titrasi Asam-Basa

Berbasis Android Terintegrasi Model

Discovery Learning dan Soal-soal HOTS berdasarkan BSNP (2014) memiliki empat aspek, yaitu kelayakan isi, kelayakan bahasa, kelayakan penyajian dan kelayakan kegrafikan. Persentase kelayakan untuk setiap aspek berdasarkan penilaian validator secara keseluruhan berada di atas 90\% dimana rata-rata persentase kelayakan oleh validator 1 adalah $94,72 \%$, validator 2 adalah $96,14 \%$, validator 3 adalah $99,10 \%$, validator 4 adalah $95,00 \%$, dan validator 5 sebesar $98,11 \%$ artinya kualitas produk yang dikembangkan dikategorikan "Sangat Layak"

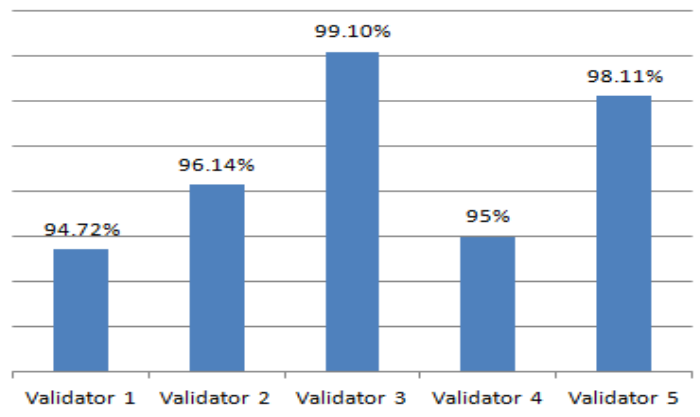

Gambar 2. Diagram Persentase Rata-Rata Hasil Validasi untuk setiap Ahli

\section{c. Uji Coba Lapangan}

Uji coba lapangan dilakukan setelah tahap validasi. Uji pengembangan dilakukan dengan meminta tanggapan siswa dan guru terhadap Handout Titrasi Asam-Basa Berbasis Android Terintegrasi Model Discovery Learning dan Soal-soal HOTS. Instrumen yang digunakan untuk memperoleh tanggapan berupa angket yang menggunakan Skala Guttman. Dengan menggunakan skala Guttman, peneliti mendapat jawaban berani "Ya" dan "Tidak". Sebelum meminta tanggapan siswa, peneliti 
terlebih dahulu memakai produk yang dikembangkan. Pengenalan produk dilakukan secara online menggunakan Zoom Meeting. Setelah pengenalan produk, peneliti mengirimkan link google form yang berisi angket untuk mendapatkan respon siswa. Sedangkan untuk guru pengenalan aplikasi dilakukan pada tahap validasi dan respon diperoleh secara offline. Instrumen untuk memperoleh respon siswa dan guru terdiri dari beberapa aspek antara lain: $\mathbf{A}$ : Kemudahan Pemahaman, B: Kemandirian Belajar, C: Keaktifan Belajar, D: Minat terhadap Handout, E: Penyajian Handout, $\mathbf{F}$ : Penggunaan Handout, dan G: Handout Titrasi Asam-Basa Berbasis Android Terintegrasi Model Discovery Learning dan Soal-soal HOTS. Hasil tanggapan siswa dan guru adalah sebagai berikut:

1. Respon Siswa

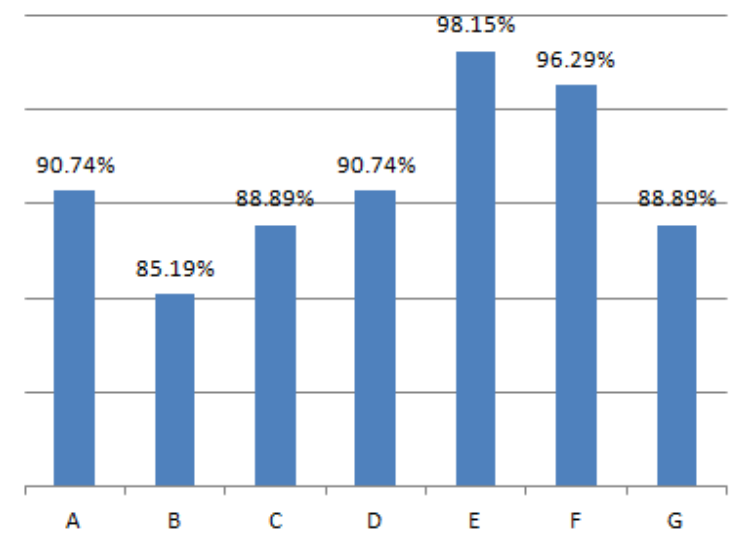

Gambar 3. Diagram Persentase Respon Siswa

Berdasarkan diagram pada Gambar

3. dapat dilihat bahwa siswa memberikan respon positif terhadap produk yang dikembangkan. Hal ini dibuktikan dengan tingginya persentase tanggapan mereka. Aspek Kemudahan Memahami diperoleh persentase 90,74\% (Sangat Baik), Aspek Kemandirian Belajar 85,19\% (Baik), Aspek Keaktifan Belajar 88,89\% (Sangat Baik), Aspek Minat pada Handout 90,74\% (Sangat Baik), Aspek Penyajian Handout 98,15\% (Sangat Baik), Aspek Penggunaan Handout 96,29\% (Sangat Baik), serta keseluruhan respon terhadap handout yang berkembang sebanyak $88,89 \%$ (Sangat Baik), yang kategori- kategorinya berdasarkanwhich categories- the categories are based on

2. Respon Guru

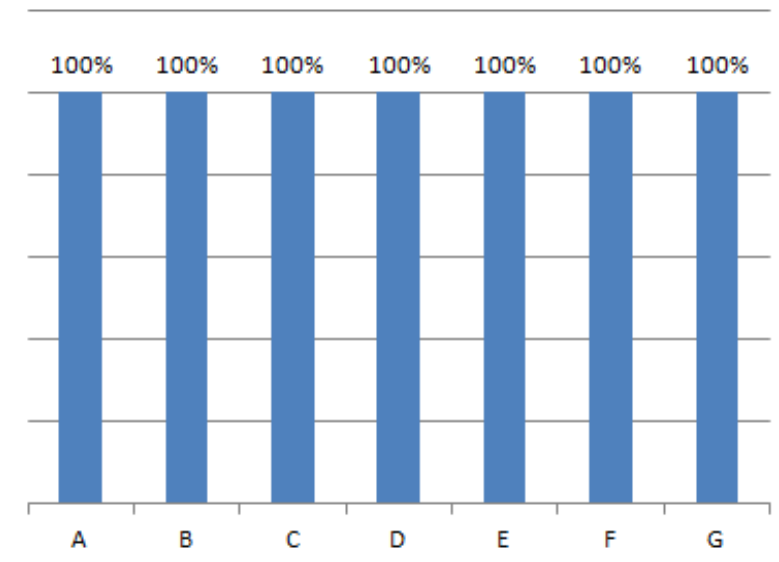

Gambar 4. Diagram Persentase Respon Guru

Dalam uji coba lapangan ini juga ditanyakan tanggapan kepada guru. Hasil respon 2 orang guru kimia SMA Negeri 10 Medan terhadap Handout Titrasi Asam-Basa Berbasis Android Terintegrasi Model Discovery Learning dan Soal-soal HOTS ditunjukkan pada diagram pada Gambar 4. Berdasarkan hasil tersebut dapat diketahui bahwa kedua guru memberikan respon yang sangat positif dengan persentase $100 \%$ yang dikategorikan sangat baik.

\section{Tahap Disseminate}

Tahap ini dilakukan dengan mengunggah aplikasi yang telah melewati beberapa tahap validasi revisi oleh ahli. Tujuan pengunggahan aplikasi di Playstore adalah untuk membuat Handout Titrasi Asam-Basa Berbasis Android Terintegrasi Model Discovery Learning dan Soal-soal HOTS yang dikembangkan untuk digunakan oleh masyarakat dalam proses belajar mengajar kimia materi titrasi asam basa.

\section{DISKUSI}

Penelitian ini merupakan penelitian dan pengembangan. Model yang diterapkan adalah 4-D yaitu Define, Design, Develop, dan Disseminate oleh Thiagarajan. Produk yang dihasilkan berupa Handout Titrasi Asam-Basa Berbasis Android Terintegrasi Model Discovery Learning dan Soal-soal HOTS. Hasil penelitian menunjukkan siswa 
kekurangan sumber belajar pada masa pandemi covid-19, sumber belajar yang digunakan berisi penjelasan panjang lebar yang sulit dipahami, tidak menerapkan pendekatan saintifik, tidak dilengkapi dengan banyak soal HOTS, dan belum berbasis android sekalipun. padahal kebanyakan siswa sudah memiliki android.

Oleh karena itu, format handout yang tepat dipilih karena handout berisi materi kompleks yang diperoleh dari berbagai sumber dengan bahasa sederhana yang mudah dipahami. Pada tahap define peneliti juga melakukan analisis terhadap siswa. Analisis dilakukan terhadap kebutuhan belajar siswa pada mata pelajaran kimia dan gaya belajar siswa. Hasil analisis menunjukkan bahwa persentase siswa yang menyukai pelajaran kimia hanya $14,8 \%$ sedangkan biologi lebih tinggi yaitu 25,9\%. Tidak hanya itu, 70,4\% siswa menyatakan bahwa pelajaran kimia kurang menyenangkan dan $51,9 \%$ siswa menyatakan kesulitan dalam tutup titrasi asam basa. Untuk gaya belajar, hasil analisis menunjukkan bahwa $33 \%$ siswa memiliki gaya belajar visual, $30 \%$ kinestetik, $15 \%$ visual kinestetik, $11 \%$ auditory kinestetik, $7 \%$ auditory, dan $4 \%$ visual auditory. Selanjutnya peneliti melakukan analisis tugas, analisis konsep, dan penentuan tujuan pembelajaran dengan mengacu pada silabus. Berdasarkan hasil analisis front end dan hasil analisis siswa maka peneliti sangat tepat untuk mengembangkan "Handout Titrasi Asam-Basa Berbasis Android Terintegrasi Model Discovery Learning dan Soal-soal HOTS". Hal ini juga didukung oleh pernyataan siswa yang menyatakan bahwa mereka menyukai pembelajaran bebasis penemuan.

Tahap kedua adalah desain. Tahapan ini terdiri dari pemilihan media, pemilihan format, dan desain awal. Media yang dipilih adalah android karena hasil wawancara dengan guru menyatakan sebagian besar siswa sudah memiliki android namun belum maksimal untuk proses belajar mengajar. Format yang dipilih adalah handout karena siswa menginginkan sumber belajar dengan penjelasan yang singkat dan bahasa yang sederhana sehingga mudah dipahami. Sedangkan desain awal berupa draft handout yang disusun dengan menggunakan Microsoft word 2007. Bagian-bagian dari draft tersebut adalah profil penyusun, kompetensi, materi, link video pembelajaran dari youtube, praktikum, dan soal HOTS.

Soal HOTS yang disertakan diambil dari penelitian pengembangan soal HOTS untuk titrasi asam basa dan modifikasi soal yang sudah valid dari beberapa buku teks kimia. Soal-soal tersebut divalidasi kembali oleh para ahli dari aspek materi, konstruksi, dan bahasa. Hasilnya, dari 35 soal yang dibuat, ada 2 soal yang tidak valid.

Tahap ketiga adalah develop. Tahapan ini terdiri dari pembuatan produk, validasi, dan uji coba lapangan. Pembuatan produk menggunakan aplikasi sketchware. Aplikasi ini dipilih karena harga belinya yang tidak mahal dan banyak tutorial penggunaanya terdapat di youtube. Setelah produk jadi, kelayakannya kemudian divalidasi oleh 5 orang ahli yaitu 3 orang dosen dan 2 orang guru. Aspek yang divalidasi meliputi Kelayakan Isi, Kelayakan Bahasa, Kelayakan Presentasi, dan Kelayakan Kegrafikan. Hasil validasi dari 5 ahli menunjukkan bahwa produk termasuk dalam kategori "Sangat Layak" karena ratarata persentase hasil validasi dari 5 ahli berada di atas $90 \%$ yaitu masing-masing 94,72\%; 96,14\%; 99,10\%; 95,00\%; dan 98,11\%. Meski begitu, ada beberapa revisi yang harus diperbaiki yaitu dari segi bahasa, kelengkapan peta konsep, dan tampilan peta konsep. Setelah melalui proses validasi, langkah selanjutnya adalah uji coba lapangan. Langkah ini dilakukan dengan meminta tanggapan siswa dan guru terhadap produk yang dikembangkan. Respon tersebut memuat 7 aspek, yaitu Kemudahan Pemahaman, Kemandirian Belajar, Keaktifan Belajar, Ketertarikan pada Handout, Penyajian Handout, Penggunaan Handout, dan keseluruhan aspek dari produk yang dikembangkan. Hasil tanggapan siswa yaitu, Aspek Kemudahan Memahami 90,74\% (Sangat Baik), Aspek Kemandirian Belajar 
85,19\% (Baik), Aspek Keaktifan Belajar 88,89\% (Sangat Baik), Aspek Minat Handout 90,74\% (Sangat Baik). Baik), Penyajian Handout 98,15\% (Sangat Baik), Penggunaan Handout 96,29\% (Sangat Baik), serta keseluruhan respon terhadap handout yang dikembangkan sebanyak $88,89 \%$ (Sangat Baik). Hal senada juga didapatkan dari tanggapan 2 guru kimia. kedua guru memberikan respon yang sangat baik dengan persentase masing-masing aspek adalah $100 \%$.

Tahap terakhir adalah disseminate. Pada tahap ini dilakukan dengan mengunggah aplikasi yang telah direvisi ke Playstore. Tujuannya agar aplikasi dapat diakses oleh mahasiswa dengan mudah. Keunggulan bahan ajar yang dikembangkan adalah memiliki format handout, berbasis Android, terintegrasi dengan model discovery learning, dan dilengkapi dengan banyak soal HOTS.

\section{KESIMPULAN}

Handout di internet memiliki kelemahan yaitu tidak dilengkapi KI, KD, Indikator, gambar, ilustrasi, dan soal HOTS. Selain itu tujuan pembelajaran kurang sistematis, cakupan materi dan penjelasan tidak luas dan tidak mendalam serta tidak mengintegrasikan pendekatan saintifik sehingga tidak merangsang rasa ingin tahu siswa. Handout Titrasi Asam-Basa Berbasis Android Terintegrasi Model Discovery Learning dan Soal-soal HOTS dikategorikan sangat layak berdasarkan aspek isi, bahasa, penyajian, dan kegrafikan. Respon siswa dan guru terhadap Handout Titrasi Asam-Basa Berbasis Android Terintegrasi Model Discovery Learning dan Soal-soal HOTS dikategorikan sangat baik pada setiap aspek dengan rata-rata persentase 91.27 dan $100 \%$.

\section{DAFTAR PUSTAKA}

Abdullah, Albeta, S. W., \& Ardiansyah. (2018). Profile Of Chemical Teacher Candidates ' Higher Order Thinking Skills (HOTS) on Ionic Equilibrium In Solution Topic. Unnes Science
Educational Journal, 7(3), 300-305.

Anggraini, D. (2018). Pengembangan Soal Kimia Berbasis Berpikir Tingkat Tinggi Materi Hidrolisis Garam Kelas XI SMA. Universitas Sriwijaya.

Chinetha, K., Joann, J. D., \& Shalini, A. (2015). An Evolution of Android Operating System and Its Version. International Journal of Engineering and Applied Sciences (IJEAS), 2(2), 3033.

Djami, C. B. N., \& Kuswandono, P. (2020). Teachers' Strategies to Implement Higher-Order Thinking Skills in English Instruction. Metathesis: Journal of English Language Literature and Teaching, 4(1), 25-40. https://doi.org/10.31002/metathesis.v4i1 .2048

Ellizar, E., Putri, S. D., Azhar, M., \& Hardeli, H. (2019). Developing a discovery learning module on chemical equilibrium to improve critical thinking skills of senior high school students. The 2018 International Conference on Research and Learning of Physics, 1-8. https://doi.org/10.1088/17426596/1185/1/012145

Fatikhakh, N., Maftukhin, A., \& Fatmaryanti, S. D. (2018). Pengembangan Handout Fisika Berbasis CORE (Connecting, Organizing, Reflecting and Extending) untuk Meningkatkan Higher Order Thinking Skills pada Peserta Didik SMA. RADIASI: Jurnal Berkala Pendidikan Fisika Volume, 11(1), 2534.

Feriyanti, D. (2014). Discovery Learning As A Method to Teach Descriptive Text in Building Students' Character: A Case of Seventh Grade Students of SMPN 3 Ulujami. Jurnal Universitas PGRI Semarang, 5(2), 58-69.

Gay, L. R., Mills, G. E., \& Airasian, P. (2012). Educational Research: Competencies for Analysis and Applications. Pearson Education, Inc.

Habiddin, \& Page, E. . (2019). Measuring Indonesian Chemistry students ' Higher Order Thinking Skills (HOTS) in 
solving chemical kinetics questions. Empowering Science and Mathematics for Global Competitiveness, 215-222. https://doi.org/10.1201/978042946190332

Harianto, A., Suryanti, \& Khery, Y. (2017). Pengembangan Media Pembelajaran Kimia Berbasis Android untuk Penumbuhan Literasi Sains Siswa Pada Materi Reaksi Redoks Dan Elektrokimia. 5(2), 35-47.

Haris, M., Jadoon, B., Yousaf, M., \& Khan, F. H. (2017). Evolution of Android Operating System: A Review. 2nd International Conference on Advanced Research (ICAR), 125-135.

Harta, J., Rasuh, N. T., \& Seriang, A. (2020). Using HOTS-Based Chemistry National Exam Questions to Map the Analytical Abilities of Senior High School Students. Journal of Science Learning, 3(3), 143-148. https://doi.org/10.17509/jsl.v3i3.22387

Khabibah, E. N., Masykuri, M., \& Maridi. (2017). The Effectiveness of Module Based on Discovery Learning to Increase Generic Science Skills. Journal of Education and Learning, 11(2), 146153.https://doi.org/10.11591/edulearn.v $11 \mathrm{i} 2.6076$

Lubis, I. R., \& Ikhsan, J. (2015). Pengembangan Media Pembelajaran Kimia Berbasis Android Untuk Meningkatkan Motivasi Belajar dan Prestasi Kognitif Peserta Didik SMA. Jurnal Inovasi Pendidikan IPA, I(2), 191-201.

https://doi.org/10.21831/jipi.v1i2.7504

Marzuki, H., \& Astuti, R. T. (2017). Analisis Kesulitan Pemahaman Konsep Pada Materi Titrasi Asam Basa Siswa SMA. Jurnal Pendidikan Kimia, 1(1), 22-27.

Munawaroh, I. (2014). Pengembangan Bahan Pembelajaran Cetak. Universitas Negeri Yogyakarta.

Prasetyo, Y. D., Ikhsan, J., \& Sari, R. L. P. (2014). The Development Of AndroidBased Mobile Learning Media As Chemistry Learning For Senior High School On Acid Base, Buffer Solution,
And Salt Hydrolysis. Proceeding of International Conference On Research, Implementation And Education Of Mathematics And Sciences 2014, Yogyakarta State University, 113-122.

Ramadhani, D. G., Mulyani, B., \& Utomo, B. S. (2016). Pengaruh Penggunaan Media Mobile Learning Berbasis Android Dan Lks Dalam Model Pembelajaran Student Team Achivement Division ( Stad ) Terhadap Prestasi Belajar Ditinjau Dari Kemampuan Memori Pada Materi Pokok Sistem Koloid Kelas Xi Sma Negeri 2 Purwokerto. Jurnal Pendidikan Kimia (JPK), 5(4), 16-25.

Sinambela, P. N. J. M. (2013). Kurikulum 2013 Dan Implementasinya Dalam Pembelajaran. Jurnal Generasi Kampus, 6(2), 17-29.

Sumantri, M. . (2015). Strategi Pembelajaran: Teori dan Praktek di Tingkat Pendidikan Dasar. PT Rajagrafindo Persada.

Tafonao, T. (2018). Peranan Media Pembelajaran Dalam Meningkatkan Minat Belajar Siswa. 2(2).

Ulfa, A. M., Sugiyarto, K. H., \& Ikhsan, J. (2017). The Effect of the Use of Android-Based Application in Learning Together to Improve Students Academic Performance. Proceedings of the International Conference on Education, Mathematics and Science 2016 (ICEMS2016) in Conjunction with 4th International Postgraduate Conference on Science and Mathematics 2016 (IPCSM2016), 050008. https://doi.org/10.1063/1.4983910

Ulya, R., Sari, S. A., \& Ismayani, A. (2015). Pengembangan Handout Berbasis Guided Note Taking Pada Materi Koloid Kelas XI MAN Banda Aceh 1Tahun Pelajaran 2015 / 2016. Jurnal Ilmiah Mahasiswa Pendidikan Kimia (JIMPK), 1(4), 115-124. 